Ljiljana M. Babincev ${ }^{1 *}$, Ivana Sredović Ignjatović ${ }^{2}$, Dragan M. Stević ${ }^{1}$

${ }^{1}$ University of Priština, Faculty of Technical Sciences, Kosovska Mitrovica, Serbia, ${ }^{2}$ University of Belgrade, Faculty of Agriculture, Belgrade, Serbia
Scientific paper

ISSN 0351-9465, E-ISSN 2466-2585

UDC:631.428:546.8

doi:10.5937/ZasMat1702235B

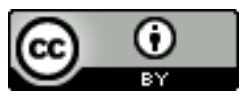

Zastita Materijala 58 (2)

$235-242(2017)$

\title{
Determination of heavy metals in soil and biomass by the application of potentiometric stripping analysis
}

\begin{abstract}
In this paper the determination of lead, cadmium and zinc in soil and biomass was performed using potentiometric stripping analysis (PSA). In order to establish the optimal experimental conditions for PSA of $\mathrm{Pb}, \mathrm{Cd}$ and $\mathrm{Zn}$, the influence of $\mathrm{pH}$ value, time of metals extraction, stirring rate of the solution and the thickness of the mercury layer, as the working electrode, was investigated. The influence of mentioned parameters was tested for individual and simultaneous metals determination. The achieved limits of determination of single ions were for: lead $22.5 \mu \mathrm{g}$ $\mathrm{dm}^{-3}$, cadmium $16.2 \mu \mathrm{g} \mathrm{dm}^{-3}$ and zinc $18.8 \mu \mathrm{g} \mathrm{dm}^{-3}$. The obtained results deviated from the expected for $1.1 \%, 1.9 \%$ and $1.8 \%$, for lead, cadmium and zinc, respectively.

For simultaneous determination, the method is tested using the ions contents as follows: $45.0 \mu \mathrm{g}$ $\mathrm{dm}^{-3}$ for lead, $32.5 \mu \mathrm{g} \mathrm{dm}^{-3}$ for cadmium and $37.5 \mu \mathrm{g} \mathrm{dm}$ for zinc. The relative errors for simultaneous determination were: $4.6 \%$ for lead, $1.9 \%$ for cadmium and $1.9 \%$ for zinc. For the established optimal conditions, except for lead, deviations did not exceed $\pm 2 \%$. It is shown that potentiometric stripping analysis is usable for individual and simultaneous determination of lead, cadmium and zinc in soil and biomass.
\end{abstract}

Key words: lead, cadmium, zinc, potentiometric stripping analysis, soil, biomass.

\section{INTRODUCTION}

Heavy metals are naturally present in the soil from which they are mainly adopted by plants, and include in the food chain [1-3]. Although presented in traces, heavy metals are characterized by toxic effects. Testing area was the northern part of Kosovo and Metohija. This part is directly affected by 100 millions of tons of existing flotation landfills of Trepca, which occupy an area of about 350 ha. The potentiometric stripping analysis (PSA) was used to determine traces of heavy metals in a soil and biomass samples from Trepca flotation landfills surrounding $[4,5]$. Determination of metals by PSA is based on electrochemical reduction of the present ions and subsequent chemical oxidation of the metals deposited on the working electrode. In PSA the analytes are deposited at the mercury film as working electrode, with the constant deposition (reduction) potential, during a predetermined

\footnotetext{
${ }^{*}$ Corresponding author: Ljiljana Babincev

E-mail: Ijiljana.babincev@pr.ac.rs

Paper received: 20. 03. 2017.

Paper accepted: 05. 05. 2017.

Paper is available on the website: www.idk.org.rs/journal
}

deposition time. Then the applied deposition potential is switched off, extracted metals are oxidized with oxygen containing in the solution, and the potential of the working electrode (measured as voltage) is measured as a function of the time [6-8]. This dependence is proportional to metal concentration. The potential of the working electrode does not change until analyzed element is oxidized. After complete oxidation of one metal, the potential of working electrode increases to the characteristic value, at which oxidation of another metal takes place [9-12].

The aim of this study was to establish optimal conditions for the individual and simultaneous PSA determination of lead, cadmium and zinc and use of PSA method for determination of these metals in real samples such as soil and grass.

\section{EXPERIMENTAL}

\subsection{Apparatus}

The experimental measurements were performed using the computerized Potentiometric Striping analyzer M1 (Faculty of Technology, Novi Sad, and Symmetry, Leskovac, Serbia). The threeelectrode system was used: mercury film deposited on glassy carbon disk, with area of $7.07 \mathrm{~mm}^{2}$, 
served as working electrode; reference electrode was silver-silver chloride electrode $(\mathrm{Ag} / \mathrm{AgCl} / \mathrm{KCl} /$ $/ 3.5 \mathrm{~mol} \mathrm{dm}^{-3}$ ) according to which all potentials are referred and a platinum wire as auxiliary electrode. Metals contents were determined by standard addition method.

\subsection{Reagents}

All the solutions were prepared from high purity chemicals (supprapur, Merck). The working solutions were prepared by diluting lead, cadmium, zinc and mercury stock standard solutions $(1,000 \mathrm{~g}$ $\left.\mathrm{dm}^{-3}\right)$. Concentration of working solutions were in the range from 50 to $99 \mathrm{mg} \mathrm{dm}^{-3}$ as follows: for lead $90 \mathrm{mg} \mathrm{dm}^{-3}$, for zinc $75 \mathrm{mg} \mathrm{dm}^{-3}$, and for cadmium $65 \mathrm{mg} \mathrm{dm}^{-3}$. For the experiments hydrochloric acid $(\mathrm{HCl}, 30 \%)$, nitric acid $\left(\mathrm{HNO}_{3}\right.$, $65 \%)$, acetone $\left(\mathrm{CH}_{3} \mathrm{COCH}_{3}, 99.5 \%\right)$, copper(II) sulfate $\left(\mathrm{CuSO}_{4}\right)$ and gallium(III) chloride $\left(\mathrm{GaCl}_{3}\right)$ were also used. The solutions were stored in polyethylene bottles.

\subsection{Sample preparation}

Soil and grass (forest biomass) samples were analyzed in this study. All analyses were carried out from aqueous solutions, which required previous sample preparation. For this purpose, 2.0 $\mathrm{g}$ of soil sample was dried at $105{ }^{\circ} \mathrm{C}$ to constant mass, homogenized and sieved through sieves with the openings less than $125 \mu \mathrm{m}$. After drying, sample of biomass was ashed at $500{ }^{\circ} \mathrm{C}$. Dissolution of $1.0 \mathrm{~g}$ of dried soil sample or biomass ash was performed by digestion with concentrated nitric and chloride acid. The digested solutions were evaporated to dryness and the remaining mass was dissolved in $\mathrm{HCl}(2$ mass \%) and diluted to $100 \mathrm{~cm}^{3}$ [13-16].

\subsection{Procedure}

Metal determination was preceded by the formation of the mercury film working electrode on the surface of glassy carbon. For this, the acidic solution of mercury(II) ion (10 $\mathrm{mg} \mathrm{dm}^{-3}$ ) was used and deposition was performed at a constant current of $48.90 \mu \mathrm{A}$ for the time of $240 \mathrm{~s}$. In order to achieve the optimal conditions for PSA determination of investigated metals, the series of solutions (model solutions) were prepared by adding $0.5-200 \mu \mathrm{l}$ of working standard solutions of lead, cadmium and zinc in $20.0 \mathrm{~cm}^{3}$ of deionized water [17]. Extraction (deposition, reduction) of lead, cadmium and zinc from the prepared model solutions was carried out at potentials of: $E_{d}(P b)=$ $-0.999 \mathrm{~V}, \mathrm{E}_{\mathrm{d}}(\mathrm{Cd})=-1.106 \mathrm{~V}$ and $\mathrm{E}_{\mathrm{d}}(\mathrm{Zn})=-1.350$ $V$. The extraction potential for subsequent simultaneous determination of all three metals was more negative: $E_{d}(P b, C d, Z n)=-1.400 \mathrm{~V}$. The simultaneous determination of metals was performed after adjusting the $\mathrm{pH}$ and potential of extraction (reduction) because in the electrolysis of strongly acidic solutions, at the reduction potential that is more negative than $-1 \mathrm{~V}$, the electrochemical separation of hydrogen at the working electrode occurs. For this reason, the value of the deposition potential has to be increased for the overvoltage of hydrogen on the metals tested. Simultaneous determination of metals was carried out after addition of $\mathrm{Ga}$ (III) ions, in order to prevent the formation of intermetallic compounds of zinc and possibly in the sample present copper [9]. The formed $\mathrm{Zn}-\mathrm{Cu}$ intermetallic compound leads to a decreasing of zinc oxidation signal, which intensity depends on the ratio of copper to zinc. Studies were performed in model solutions with zinc concentrations of: $37.5,187.5$, and $375.0 \mu \mathrm{g} \mathrm{dm}^{-3}$, and copper concentrations of 10.0, 20.0, 30.0 and $35.0 \mu \mathrm{g} \mathrm{dm}^{-3}$. It was found that interference in the determination of zinc can come from the copper concentrations less than $10.0 \mathrm{\mu g} \mathrm{dm}^{-3}$ with an error of up to $30 \%$. By adding gallium of $40.0 \mu \mathrm{g} \mathrm{dm}^{-3}$ in solutions with the copper concentration of $35.0 \mu \mathrm{g}$ $\mathrm{dm}^{-3}$, and wide range of zinc concentration, the formation of $\mathrm{Zn}-\mathrm{Cu}$ compound is prevented because more stable compound of gallium and copper is formed.

In order to define the optimal conditions for determination, the influence of the following parameters was particularly examined: $\mathrm{pH}$ value of the supporting electrolyte; stirring rate of solution, time of metals deposition and time of working electrode formation. After the optimal conditions were established, the determination of lead, cadmium and zinc in real samples of soil and biomass (grass) was performed.

\section{RESULTS AND DISCUSSION}

\subsection{Individual metals determinations}

The influence of acidity of the solution on the efficiency of determination was examined in the $\mathrm{pH}$ value range from 1.3-4.5. The metal concentrations were: $224.3 \mathrm{\mu g} \mathrm{dm}^{-3}(\mathrm{~Pb}), 162.0 \mathrm{\mu g} \mathrm{dm}^{-3}(\mathrm{Cd})$ and $375.0 \mu \mathrm{g} \mathrm{dm}^{-3}(\mathrm{Zn})$. It was found that the obtained results deviate by $\pm 2 \%$ when the determinations were performed in solutions at $\mathrm{pH}$ 1.3, 1.6 and 2.0. The ratio of oxidation time to concentration, represented as the constant of potentiometric stripping analysis $\left(K / \mathrm{s} \mathrm{dm} \mathrm{mol}^{-1}\right)$, has the highest value for $\mathrm{Pb}$ when determination was performed from solution $\mathrm{pH} 1.6$, for $\mathrm{Cd}$ from solution $\mathrm{pH} 1.6$ and 2.0, and for $\mathrm{Zn}$ from the solution $\mathrm{pH} 2.1-3.5$. PSA metals determination was performed at $\mathrm{pH} 2.1$, because for preset $\mathrm{pH}$ value, the constants of potentiometric stripping analyses for all three metals have the comparable values (Figure 1). 


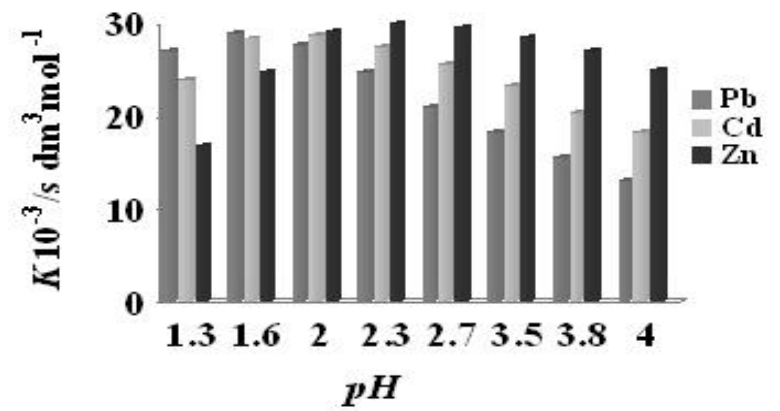

Figure. 1. Dependence of the potentiometric stripping analysis constants for determination of lead, cadmium and zinc on $\mathrm{pH}$ value

Slika 1. Zavisnost konstante potenciometrijske striping analize za određivanje olova, kadmijuma i cinka od $\mathrm{pH}$ vrednosti rastvora

The influence of stirring rate on the determination of metals was investigated in the range of 1000-6000 $\mathrm{min}^{-1}$. The most efficient determinations were made at the stirring rate of $4000 \mathrm{~min}^{-1}$. This can be explained as the consequence of the formation of the optimal thickness of diffusion layer at the electrode/solution surface. Metal extraction from the solution was investigated for the time of: $180,240,300,360$ and $420 \mathrm{~s}$. The results of the determination showed that the most efficient metal extraction is achieved for the electrolysis time of $300 \mathrm{~s}$. Under the mentioned conditions, the measured concentrations deviated from the expected for: $1.05 \%, 1.90 \%$ and $1.94 \%$ for $\mathrm{Pb}, \mathrm{Cd}$ and $\mathrm{Zn}$, respectively. When the minimal time employed for metal extraction is $240 \mathrm{~s}$, metal contents deviated from expected by: $3.34 \%$ for lead, $3.0 \%$ for cadmium and $3.76 \%$ for zinc.

The influence of the mercury layer thickness on metal determination was analyzed as the time required for the formation of the working electrode. The working electrode formation was done by deposition the mercury on glassy carbon within: $120,180,240,300$ and 360 s. A good reproducibility was obtained for determination of all three ions when the mercury layer was formed within 240 $\mathrm{s}$. The mercury layer formed in $240 \mathrm{~s}$, based on reproducibility, provides a good homogenization of extracted metal ions, faster dissolution process and better separation.

In order to determine detection limits of potentiometric analysis for lead, cadmium and zinc, solutions of $20.0 \mathrm{~cm}^{3}$ of deionized water and different working standard volumes from 0.5 to 600 $\mu \mathrm{l}$ were prepared. Metal extraction was performed within $300 \mathrm{~s}$; solution stirring rate was $4000 \mathrm{~min}^{-1}$ and at the $\mathrm{pH}$ values of 1.6 for lead and cadmium and 2.1 for zinc. The results of determination are presented in Tables 1 - 3.
Table 1. The results of determination of lead concentration in model solutions $(n=5)$

Tabela 1. Rezultati određivanja koncentracije olova u model rastvorima( $n=5)$

\begin{tabular}{|c|c|c|c|c|}
\hline \multicolumn{2}{|c|}{$\begin{array}{c}\text { Concentration of lead, } \\
\mu \mathrm{g} \mathrm{dm}^{-3}\end{array}$} & \multirow{2}{*}{$\mathcal{S}^{\mathrm{c}} / \mu \mathrm{g}$} & \multirow{2}{*}{$K_{\mathrm{v}}{ }^{\mathrm{d}} \%$} & \multirow{2}{*}{$E_{\mathrm{r}}^{\mathrm{e}} \%$} \\
\cline { 1 - 2 }$X_{\mathrm{s}}^{\mathrm{a}}$ & $\bar{X}^{\mathrm{b}}$ & & & \\
\hline 2.25 & 2.38 & 0.30 & 12.6 & 5.78 \\
\hline 4.45 & 4.70 & 0.58 & 12.3 & 5.62 \\
\hline 22.5 & 25.0 & 2.52 & 11.3 & 1.12 \\
\hline 45.0 & 45.4 & 5.15 & 11.3 & 1.02 \\
\hline 89.8 & 90.8 & 7.56 & 8.33 & 1.05 \\
\hline 224 & 227 & 18.2 & 8.01 & 1.03 \\
\hline 448 & 452 & 32.9 & 7.28 & 1.05 \\
\hline 891 & 881 & 63.9 & 7.26 & 1.14 \\
\hline 1319 & 1299 & 98.0 & 7.55 & 1.60 \\
\hline 1764 & 1731 & 134 & 7.74 & 1.84 \\
\hline 2194 & 2151 & 169 & 7.87 & 1.98 \\
\hline 2700 & 2430 & 198 & 8.15 & 10.0 \\
\hline
\end{tabular}

${ }^{a} X_{\mathrm{s}}$-concentration of lead in the model solution, ${ }^{b} \bar{X}$. average measured concentration, ${ }^{\circ} S$-standard deviation, ${ }^{\mathrm{d}} \mathrm{K}_{\mathrm{V}}$-coefficient of variation, ${ }^{\mathrm{e}} \mathrm{Er}$ error of determination

Table 2. The results of determination of cadmium concentration in model solutions $(n=5)$

Tabela 2. Rezultati određivanja koncentracije kadmijuma u model rastvorima $(n=5)$

\begin{tabular}{|c|c|c|c|c|}
\hline \multicolumn{2}{|c|}{$\begin{array}{c}\text { Concentration of cadmium, } \\
\mu \mathrm{g} \mathrm{dm}\end{array}$} & \multirow{2}{*}{$\mathcal{S}^{\mathrm{c}} / \mu \mathrm{g}$} & \multirow{2}{*}{$K_{\mathrm{v}}^{\mathrm{d}} / \%$} & \multirow{2}{*}{$E_{\mathrm{r}}^{\mathrm{e}} / \%$} \\
\hline$X_{\mathrm{s}}^{\mathrm{a}}$ & $\bar{X}^{\mathrm{b}}$ & & & \\
\hline 3.25 & 3.45 & 0.47 & 13.7 & 6.15 \\
\hline 16.2 & 16.5 & 1.56 & 9.45 & 1.91 \\
\hline 32.5 & 33.1 & 2.49 & 7.54 & 1.90 \\
\hline 64.9 & 66.1 & 4.98 & 7.53 & 1.89 \\
\hline 162 & 165 & 12.2 & 7.39 & 1.90 \\
\hline 323 & 329 & 24.5 & 7.43 & 1.88 \\
\hline 643 & 634 & 45.6 & 7.19 & 1.41 \\
\hline 960 & 941 & 68.7 & 7.30 & 1.93 \\
\hline 1274 & 1243 & 106 & 8.51 & 2.40 \\
\hline 1585 & 1536 & 137 & 8.64 & 3.04 \\
\hline 1892 & 1790 & 156 & 8.72 & 5.42 \\
\hline
\end{tabular}

${ }^{a} X_{\mathrm{S}}$-concentration of cadmium in the model solution, ${ }^{\mathrm{b}} \bar{X}$. average measured concentration, ${ }^{\mathrm{C}} S$-standard deviation, ${ }^{\mathrm{d}} \mathrm{K}_{\mathrm{V}}$-coefficient of variation, ${ }^{\mathrm{e}} \mathrm{E}_{\mathrm{r}}$-error of determination

From the presented results it can be seen that the minimum concentrations of lead, cadmium and zinc which can be determined with an maximal error of $\pm 2 \%$ (for 5 measurements) were: $22.5 \mu \mathrm{g}$ $\mathrm{dm}^{-3}$ of lead (determined with an error of $1.1 \%$ ), $16.2 \mu \mathrm{g} \mathrm{dm}^{-3}$ of cadmium (determined with an error of $1.2 \%$ ) and $18.8 \mathrm{\mu g} \mathrm{dm}^{-3}$ of zinc (determined with an error of $1.8 \%$ ). In accordance to the standard deviations and the reproducibility, these contents 
can be considered as the limits of determination. Standard deviations were $2.5 \mu \mathrm{g}$ for lead, $1.6 \mu \mathrm{g}$ for cadmium and $2.0 \mu \mathrm{g}$ for zinc. The detection limit of potentiometric stripping analysis of lead, cadmium and zinc is about $2 \mu \mathrm{g} \mathrm{dm}{ }^{-3}$. The highest concentrations that are successfully determined by PSA were: $2190 \mathrm{\mu g} \mathrm{dm}^{-3}$ for lead, $960 \mathrm{\mu g} \mathrm{dm}^{-3}$ for cadmium, and $1300 \mu \mathrm{g} \mathrm{dm}{ }^{-3}$ for zinc. These contents were determined with the error of: $2.0 \%$ for lead, $1.9 \%$ for cadmium, and $1.9 \%$ for zinc and standard deviations of: $170 \mu \mathrm{g}, 70 \mu \mathrm{g}$ and $110 \mu \mathrm{g}$ for $\mathrm{Pb}, \mathrm{Cd}$ and $\mathrm{Zn}$, respectively.

Table 3. The results of determination of zinc concentration in model solutions $(n=5)$

Tabela 3. Rezultati određivanja koncentracije cinka u model rastvorima $(n=5)$

\begin{tabular}{|c|c|c|c|c|}
\hline \multicolumn{2}{|c|}{ Concentration zinc, $\mu \mathrm{g} \mathrm{dm}{ }^{-3}$} & \multirow{2}{*}{$\mathcal{S}^{\mathrm{c}} / \mu \mathrm{g}$} & \multirow{2}{*}{$\mathcal{V}_{\mathrm{v}}^{\mathrm{d}} / \%$} & \multirow{2}{*}{$E_{\mathrm{r}}^{\mathrm{e}} \%$} \\
\hline$X_{\mathrm{s}}^{\mathrm{a}}$ & $\bar{X}^{\mathrm{b}}$ & & & \\
\hline 1.88 & 2.02 & 0.23 & 11.4 & 7.45 \\
\hline 3.75 & 3.97 & 0.46 & 11.6 & 5.86 \\
\hline 18.8 & 19.1 & 2.00 & 10.4 & 1.81 \\
\hline 37.5 & 38.2 & 3.96 & 10.4 & 1.89 \\
\hline 188 & 191 & 16.0 & 8.35 & 1.95 \\
\hline 375 & 380 & 28.2 & 7.43 & 1.27 \\
\hline 750 & 738 & 57.5 & 7.79 & 1.63 \\
\hline 1125 & 1106 & 80.8 & 7.30 & 1.65 \\
\hline 1312 & 1286 & 111 & 8.68 & 1.95 \\
\hline 1500 & 1459 & 131 & 8.95 & 2.76 \\
\hline
\end{tabular}

${ }^{a} X_{\mathrm{s}}$-concentration of elements in the standard solution,

$\mathrm{b} \frac{X^{\prime}}{X}$-average measured concentration, ${ }^{\mathrm{c}} S$-standard deviation, ${ }^{\mathrm{d}} K_{\mathrm{v}}$-coefficient of variation, ${ }^{\mathrm{e}} E_{\mathrm{r}}$-error of determination

\subsection{Simultaneous metals determinations}

The simultaneous determination of investigated metals was studied in solutions containing $45.0 \mathrm{\mu g}$ $\mathrm{dm}^{-3}$ of lead, $32.5 \mu \mathrm{g} \mathrm{dm}^{-3}$ of cadmium and $37.5 \mu \mathrm{g}$ $\mathrm{dm}^{-3}$ of zinc. Results of this study have shown that applied deposition potential of the working electrode for the simultaneous determination of lead, cadmium and zinc is $490-510 \mathrm{mV}$ more negative than the potential of zinc dissolution (an element with the lowest redox potential). It was found that all three elements can be determined using the $-1.400 \mathrm{~V}$ as the deposition potential. The simultaneous determination of lead and cadmium was optimal at $\mathrm{pH}$ value of 1.6 , while at $\mathrm{pH} 2.1$, cadmium and zinc were successfully simultaneously determined. Simultaneous determination of lead and zinc was examined using solutions with $\mathrm{pH}$ values 1.3, 1.6, 2.0, and the most effective determinations were found at $\mathrm{pH}$ 2.0. Zinc is most accurately determined at $\mathrm{pH}$ values in the range 2.3-3.5, which may partly be explained by the qualitative properties of zinc. The simultaneous determination of all three elements was performed (with the mentioned deposition potential) at pH 2.1, as compromise value, because the PSA constants for all three metals were with the values giving enough sensitive determination. With prior $\mathrm{pH}$ adjustment, metal content was determined by standard addition method. The characteristic potentials of analyte oxidation are: $\mathrm{E}_{Z n}=-(0.890 \pm 10) \mathrm{V}, \mathrm{E}_{\mathrm{Cd}}=$ $-(0.595 \pm 10) \vee$ and $E_{P b}=-(0.390 \pm 10) V$. Results of simultaneous determination of lead, cadmium and zinc are given in Table 4.

Table 4. The results of the simultaneous determination of lead, cadmium and zinc in model solution $(n=5)$

Tabela 4. Rezultati istovremenog određivanja olova, kadmijuma i cinka u model rastvorima $(n=5)$

\begin{tabular}{|c|c|c|c|c|c|c|c|c|}
\hline \multirow{2}{*}{ Ion } & \multicolumn{3}{|c|}{ Ion concentration, $\mu \mathrm{g} \mathrm{dm}^{-3}$} & \multirow{2}{*}{$\tau^{n} / s$} & \multirow{2}{*}{$\begin{array}{c}K_{\mathrm{p}} 10^{-3} \\
/ \mathrm{s} \cdot \mathrm{dm}^{3} \mathrm{~mol}^{-1}\end{array}$} & \multirow{2}{*}{$S^{c} / \mu \mathrm{g}$} & \multirow{2}{*}{$K_{\mathrm{v}}{ }^{d} / \%$} & \multirow{2}{*}{$E_{r}^{\mathrm{e}} / \%$} \\
\hline & $X_{\mathrm{s}}^{\mathrm{a}}$ & $X_{\mathrm{i}}^{\mathrm{m}}$ & $\bar{X}^{\mathrm{b}}$ & & & & & \\
\hline \multirow{5}{*}{$\mathrm{Pb}^{2+}$} & \multirow{5}{*}{45.0} & 44.6 & \multirow{5}{*}{42.9} & 1.47 & 32.8 & \multirow{5}{*}{5.57} & \multirow{5}{*}{13.0} & \multirow{5}{*}{4.58} \\
\hline & & 41.0 & & 1.31 & 32.0 & & & \\
\hline & & 43.2 & & 1.40 & 32.5 & & & \\
\hline & & 42.2 & & 1.35 & 32.1 & & & \\
\hline & & 43.3 & & 1.42 & 32.6 & & & \\
\hline \multirow{5}{*}{$\mathrm{Cd}^{2+}$} & \multirow{5}{*}{32.5} & 34.7 & \multirow{5}{*}{31.9} & 0.85 & 24.6 & \multirow{5}{*}{4.54} & \multirow{5}{*}{14.3} & \multirow{5}{*}{1.91} \\
\hline & & 32.1 & & 0.79 & 24.6 & & & \\
\hline & & 29.0 & & 0.71 & 24.5 & & & \\
\hline & & 34.0 & & 0.84 & 24.8 & & & \\
\hline & & 29.5 & & 0.72 & 24.5 & & & \\
\hline \multirow{5}{*}{$\mathrm{Zn}^{2+}$} & \multirow{5}{*}{37.5} & 41.9 & \multirow{5}{*}{36.8} & 0.90 & 21.6 & \multirow{5}{*}{4.47} & \multirow{5}{*}{12.1} & \multirow{5}{*}{1.89} \\
\hline & & 35.5 & & 0.76 & 21.5 & & & \\
\hline & & 34.2 & & 0.73 & 21.5 & & & \\
\hline & & 44.4 & & 0.96 & 21.6 & & & \\
\hline & & 36.3 & & 0.78 & 21.6 & & & \\
\hline
\end{tabular}


The obtained results suggest that there is a difference in the determinated contents when we take individual and simultaneous determinations into consideration. The results for the individual determinations deviated from the actual values by $1.0 \%$ for lead; $1.9 \%$ for cadmium and $1.9 \%$ for zinc. During the simultaneous determinations, the deviations were as follows: $4.6 \%$ for lead; $1.9 \%$ for cadmium and $1.9 \%$ for zinc. Results obtained for lead were less accurate. Since micro quantities are analysed, and relative errors of determination are less than $5 \%$, simultaneous determination of these elements is considered possible.

\subsection{Analysis of real samples}

Potentiometric stripping analysis was applied for determination of heavy metals in various real samples [18-22]. In this work, lead, cadmium and zinc in soil and biomass samples are determined. Soil samples were collected at five different locations, which are at different distance from active and passive Trepca's landfills. Soil sampling was done in Jun and August of 2015. The results for individual determination of lead, cadmium and zinc in soil samples are given in Table 5 . The same samples were used for simultaneous determination of analyzed metals. Results of simultaneous determination are shown in Table 6.

Table 5. The results of determination of lead, cadmium and zinc in soil $(n=3)$

Tabela5. Rezultati određivanja olova, kadmijuma i cinka u zemljištu ( $n=3)$

\begin{tabular}{|c|c|c|c|c|c|c|}
\hline \multirow{2}{*}{ Sampling locations } & \multicolumn{2}{|c|}{$\mathrm{Pb}$} & \multicolumn{2}{|c|}{$\mathrm{Cd}$} & \multicolumn{2}{|c|}{$\mathrm{Zn}$} \\
\hline & $\bar{X} \mathrm{~b} / \mu \mathrm{g} \mathrm{g}^{-1}$ & $\mathrm{~K}_{\mathrm{v}}{ }^{\mathrm{d}} / \%$ & $\bar{X} \mathrm{~b} / \mu \mathrm{g} \mathrm{g}{ }^{-1}$ & $\mathrm{~K}_{\mathrm{v}}{ }^{\mathrm{d}} / \%$ & $\bar{X} \mathrm{~b} / \mu \mathrm{g} \mathrm{g}^{-1}$ & $\mathrm{~K}_{\mathrm{v}}{ }^{\mathrm{d}} / \%$ \\
\hline$R$ & 158 & 8,24 & 3.70 & 13.7 & 357 & 7.47 \\
\hline $\mathrm{G}$ & 213 & 8,17 & 6.90 & 9.81 & 519 & 7.65 \\
\hline Ž & 120 & 8,13 & 34.7 & 7.45 & 226 & 7.58 \\
\hline $\mathrm{S}$ & 129 & 8,03 & 4.90 & 13.7 & 799 & 7.81 \\
\hline $\mathrm{K}$ & 373 & 7,14 & 23.5 & 8.38 & 334 & 7.54 \\
\hline$D_{B}$ & 2378 & 7,91 & 29.4 & 8.31 & 1201 & 8.05 \\
\hline $\mathrm{D}_{\check{z}}$ & 1119 & 7,62 & 9.30 & 9.75 & 753 & 7.78 \\
\hline$M C L^{\mathrm{q}} / \mathrm{\mu g} \mathrm{g}^{-1}$ & \multicolumn{2}{|c|}{100.0} & \multicolumn{2}{|c|}{3.0} & \multicolumn{2}{|c|}{300.0} \\
\hline
\end{tabular}

b $\bar{X}$-average measured concentration; ${ }^{d} K_{v}$-coefficient of variation; R-Rudare; G-Grabovac; Ž-Žitkovac; S-Srbovac; KGornji Krnjin; $D_{B}$-landfill Bostanište; Dž-landfill Žitkovac, ${ }^{9} M C L$ maximum contaminant level

Table 6. The results of the simultaneous determination of lead, cadmium and zinc in soil $(n=3)$

Tabela 6. Rezultati istovremenog određivanja olova, kadmijuma i cinka u zemljištu ( $n=3)$

\begin{tabular}{|c|c|c|c|c|c|c|}
\hline \multirow{2}{*}{ Sampling locations } & \multicolumn{2}{|c|}{$\mathrm{Pb}$} & \multicolumn{2}{|c|}{$\mathrm{Cd}$} & \multicolumn{2}{|c|}{$\mathrm{Zn}$} \\
\hline & $\bar{X} \mathrm{~b} / \mu \mathrm{g} \mathrm{g}^{-1}$ & $\mathrm{~K}_{\mathrm{v}}{ }^{\mathrm{d}} / \%$ & $\bar{X} \mathrm{~b} / \mu \mathrm{g} \mathrm{g}^{-1}$ & $\mathrm{~K}_{\mathrm{v}}{ }^{\mathrm{d}} / \%$ & $\bar{X} \mathrm{~b} / \mu \mathrm{g} \mathrm{g}^{-1}$ & $\mathrm{~K}_{\mathrm{v}}{ }^{\mathrm{d}} / \%$ \\
\hline $\mathrm{R}$ & 148 & 8.21 & 3.60 & 13.6 & 346 & 7.44 \\
\hline$G$ & 202 & 8.57 & 6.60 & 9.84 & 503 & 7.47 \\
\hline Ž & 112 & 8.02 & 33.4 & 7.49 & 217 & 7.66 \\
\hline $\mathrm{S}$ & 122 & 8.02 & 4.60 & 13.7 & 797 & 7.70 \\
\hline $\mathrm{K}$ & 353 & 7.11 & 22.6 & 8.62 & 324 & 7.53 \\
\hline$D_{B}$ & 2257 & 7.93 & 28.3 & 8.47 & 1192 & 8.01 \\
\hline $\mathrm{D}_{z}$ & 1085 & 7.74 & 8.90 & 9.91 & 751 & 7.77 \\
\hline$M C L^{\mathrm{q}} / \mathrm{\mu g} \mathrm{g}^{-1}$ & \multicolumn{2}{|c|}{100.0} & \multicolumn{2}{|c|}{3.0} & \multicolumn{2}{|c|}{300.0} \\
\hline
\end{tabular}

${ }^{\mathrm{b}} \bar{X}$-average measured concentration; ${ }^{\mathrm{d}} K_{V}$-coefficient of variation; R-Rudare; G-Grabovac; Ž-Žitkovac; S-Srbovac; KGornji Krnjin; DB-landfill Bostanište; $D_{\check{z}}$-landfill Žitkovac, ${ }^{9} M C L$ maximum contaminant level

According to the listed results, the sample from the active Trepča's landfill Bostanište has higher concentration of lead, cadmium and zinc in relation to passive Trepča's ore landfill Žitkovac. The concentration of the studied elements, at almost all investigated locations, exceeded the maximum permitted values [23]. The concentrations of metals were significantly higher in soil close to active landfill, in comparison to those in soil in the closest vicinity of a passive landfill. The lead concentration was up to twenty times higher in the active landfill. Beside the landfills, the highest concentration of lead was found in the soil of the village Gornji Krnjin, in whose closest vicinity there are both passive and active ore landfills, cadmium in soil sample from Žitkovac (close to active landfill) and 
zink in soil sample from Srbovac (farthest from both landfills).

Since biomass is an important factor in the nutrition chain, it is important to determine its quality, particularly in the aspect of heavy metals content [3]. The average critical and toxic heavy metal concentrations in plants are given in the literature [2]. Concentrations of lead, cadmium and Table 7. The results of the determination of lead, cadmium and zinc in biomass $(n=3)$

Table 7. Rezultati određivanja olova, kadmijuma i cinka u biomasi $(n=3)$

\begin{tabular}{|c|c|c|c|c|c|c|}
\hline \multirow{2}{*}{$\begin{array}{l}\text { Sampling } \\
\text { locations }\end{array}$} & \multicolumn{3}{|c|}{$\bar{X}^{\mathrm{b}} / \mu \mathrm{g} \mathrm{g}^{-1} D M^{\prime}$} & \multicolumn{3}{|c|}{$K_{v}{ }^{d} / \%$} \\
\hline & $\mathrm{Pb}$ & $\mathrm{Cd}$ & $\mathrm{Zn}$ & $\mathrm{Pb}$ & $\mathrm{Cd}$ & $\mathrm{Zn}$ \\
\hline \multirow{3}{*}{$\begin{array}{l}\text { Along main road Lešak } \\
\text {-Kos. Mitrovica }\end{array}$} & 9.70 & 3.60 & 128 & \multirow{3}{*}{12.3} & \multirow{3}{*}{13.1} & \multirow{3}{*}{8.42} \\
\hline & 7.80 & 3.90 & 130 & & & \\
\hline & 8.00 & 3.00 & 149 & & & \\
\hline \multirow{3}{*}{$\begin{array}{l}\text { Zone of passive Trepča } \\
\text { landfill Žitkovac }\end{array}$} & 26.0 & 7.70 & 169 & \multirow{3}{*}{11.6} & \multirow{3}{*}{10.3} & \multirow{3}{*}{8.53} \\
\hline & 21.8 & 8.80 & 193 & & & \\
\hline & 19.7 & 7.20 & 165 & & & \\
\hline \multirow{3}{*}{$\begin{array}{l}\text { Zone of active Trepča } \\
\text { landfill Bostanište }\end{array}$} & 134 & 9.60 & 540 & \multirow{3}{*}{8.80} & \multirow{3}{*}{10.6} & \multirow{3}{*}{8.58} \\
\hline & 117 & 7.90 & 616 & & & \\
\hline & 114 & 9.50 & 526 & & & \\
\hline Critical concentration, $\mu \mathrm{g} \mathrm{g}^{-1} D M^{\prime}$ & \multicolumn{2}{|c|}{10 for $\mathrm{Pb}$} & \multicolumn{2}{|c|}{5 for $\mathrm{Cd}$} & \multicolumn{2}{|c|}{150 for $Z n$} \\
\hline Toxic concentration, $\mu \mathrm{g} \mathrm{g}^{-1} D M^{\gamma}$ & \multicolumn{2}{|c|}{20 for $\mathrm{Pb}$} & \multicolumn{2}{|c|}{10 for $\mathrm{Cd}$} & \multicolumn{2}{|c|}{200 for $Z n$} \\
\hline
\end{tabular}

${ }^{\mathrm{b}} \bar{X}$-average measured concentration, ${ }^{\mathrm{y}} D M$-dry matter; ${ }^{\mathrm{d}} K_{\mathrm{v}}$-coefficient of variation

Table 8. The results of the simultaneous determination of lead, cadmium and zinc in biomass $(n=3)$

Tabela 8. Rezultati istovremenog određivanja olova, kadmijuma i cinka u biomasi $(n=3)$

\begin{tabular}{|c|c|c|c|c|c|c|}
\hline \multirow{2}{*}{$\begin{array}{l}\text { Sampling } \\
\text { locations }\end{array}$} & \multicolumn{3}{|c|}{$\bar{X}^{\mathrm{b}} / \mu \mathrm{g} \mathrm{g}^{-1} D M^{\phi}$} & \multicolumn{3}{|c|}{$K_{\mathrm{v}}^{\mathrm{d}} / \%$} \\
\hline & $\mathrm{Pb}$ & $\mathrm{Cd}$ & $\mathrm{Zn}$ & $\mathrm{Pb}$ & $\mathrm{Cd}$ & $\mathrm{Zn}$ \\
\hline \multirow{3}{*}{$\begin{array}{l}\text { Along main road Lešak } \\
\text {-Kos. Mitrovica }\end{array}$} & 9.10 & 3.40 & 130 & \multirow{3}{*}{14.2} & \multirow{3}{*}{13.9} & \multirow{3}{*}{8.47} \\
\hline & 7.60 & 3.70 & 133 & & & \\
\hline & 6.90 & 2.80 & 152 & & & \\
\hline \multirow{3}{*}{$\begin{array}{l}\text { Zone of passive Trepča } \\
\text { landfill Žitkovac }\end{array}$} & 24.5 & 7.10 & 163 & \multirow{3}{*}{12.3} & \multirow{3}{*}{11.2} & \multirow{3}{*}{8.61} \\
\hline & 19.7 & 7.30 & 185 & & & \\
\hline & 20.2 & 5.90 & 158 & & & \\
\hline \multirow{3}{*}{$\begin{array}{l}\text { Zone of active Trepča } \\
\text { landfill Bostanište }\end{array}$} & 128 & 8.90 & 536 & \multirow{3}{*}{9.39} & \multirow{3}{*}{11.0} & \multirow{3}{*}{8.58} \\
\hline & 111 & 7.10 & 611 & & & \\
\hline & 107 & 8.60 & 522 & & & \\
\hline Critical concentration, $\mu \mathrm{g} \mathrm{g}^{-1} D M^{\prime}$ & \multicolumn{2}{|c|}{10 for $\mathrm{Pb}$} & \multicolumn{2}{|c|}{5 for $\mathrm{Cd}$} & \multicolumn{2}{|c|}{150 for $\mathrm{Zn}$} \\
\hline Toxic concentration, $\mu \mathrm{g} \mathrm{g}^{-1} D M^{y}$ & \multicolumn{2}{|c|}{20 for $\mathrm{Pb}$} & \multicolumn{2}{|c|}{10 for $\mathrm{Cd}$} & \multicolumn{2}{|c|}{200 for $Z n$} \\
\hline
\end{tabular}

${ }^{\mathrm{b}} \bar{X}$-average measured concentration, ${ }^{\mathrm{y}} D M$-dry matter; ${ }^{\mathrm{d}} K_{v}$-coefficient of variation

Plant material samples taken along the road Lešak-Kosovska Mitrovica contained a lead concentration less than $10 \mathrm{\mu g} \mathrm{g}^{-1}$ of dry substance, which is about the limit of critical value. This is in good agreement with the literature data that the lead concentration in grass with active growth varied from $0.3-1.5 \mu \mathrm{g} \mathrm{g}^{-1}$, increasing up to $10 \mu \mathrm{g}$ $\mathrm{g}^{-1}$ at the end of the summer, while in the period of vegetation inactivity is up to $30 \mu \mathrm{g} \mathrm{g}^{-1}$ of dried substance [24]. The lead concentrations in the biomass collected close to the passive landfill were up to $30 \mathrm{\mu g} \mathrm{g}^{-1}$, and in the zone of an active landfill $135 \mu \mathrm{g}$ of lead was found in $1 \mathrm{~g}$ of dry substance (Table 8 ). The both values are above critical, as well as, toxic concentrations. In previous studies made on over-ground grasses on unpolluted soils, the measured lead values were from $1.2-9.0 \mu \mathrm{g}$, while the lead concentration in polluted soil was from 63 to $232 \mu \mathrm{g}$ in $1 \mathrm{~g}$ of dry substance $[25,26]$. 
Along the road Lešak-Kosovska Mitrovica, zinc is present within the required limits, whereas its concentration in the biomass, in the vicinity of active landfill, was up to $620 \mu \mathrm{g} \mathrm{g}^{-1}$ of dry substance, represents a toxic concentration. The zinc content in the biomass in the vicinity of passive landfill was below the toxic but in the range of critical concentrations.

Cadmium concentration in samples taken along the Lešak-Kosovska Mitrovica road was lower than critical concentration. The cadmium concentration in biomass (impact of passive and active landfill) is in the range below toxic but above critical values.

Comparing to our earlier investigations, the obtained results indicated that contents of lead, in all analysed samples, decreased over five years, cadmium concentration near active landfill is allmost two times higher, and zinc concentration did not changed signifficantly [14].

\section{CONCLUSIONS}

The objective of this study is simultaneous determination of lead, cadmium and zinc by potentiometric stripping analysis, as well as its application for soil and biomass analysis. The optimal working conditions were postulated as: extraction potential was $-1.400 \mathrm{~V}$ vs. $\mathrm{Ag} / \mathrm{AgCl}, \mathrm{KCl}$ electrode, extraction time was $300 \mathrm{~s}$, solution stirring rate $4000 \mathrm{~min}^{-1}, \mathrm{pH}$ value of the tested solution was 2.1, and time of working electrode formation was $240 \mathrm{~s}$. The results of simultaneous determination are compared with the results of individual determination and quite good agreement was found. The efficiency of the individual determination was greater due to the better synchronization of the solution $\mathrm{pH}$ value and the extraction potential for each metal individually. The described method has wide linear working range of concentrations: $(23-2190) \mu \mathrm{g} \mathrm{dm}^{-3}$ for lead, (16 $960) \mu \mathrm{gm}^{-3}$ for cadmium and $(19-1300) \mu \mathrm{g} \mathrm{dm}^{-3}$ for zinc. For the simultaneous determination of all three metals, relative error of determination was in the range of $2-5 \%$. The reproducibility of PSA measurements for lead, cadmium and zinc in the soil samples was $8-10 \%$, and in the biomass samples, the reproducibility was $8-12 \%$ for lead, $10-13 \%$ for cadmium and $9 \%$ for zinc.

The obtained results indicate that potentiometric stripping analysis is usable for determination of lead, cadmium and zinc, both individually and simultaneously, as well as in the analysis of soil and biomass.

\section{Acknowledgements}

This work is supported by the Ministry of Education and Science of the Republic of Serbia, Project No. TR37016.

\section{REFERENCES}

[1] P. Sekulić, R. Kastori, V. Hadžić (2003) Degradation soil protection, Scientific Institute for Husbandry and Vegetable Crops, Novi Sad.

[2] R. Kastori, D. Bogdanović, I. Kádár, N. Milošević, P. Sekulić, M. Pucarević (2006) Soil and plant sampling in unpolluted and polluted habitats, Scientific Institute for Husbandry and Vegetable Crops, Novi Sad.

[3] R. Kastori (1997) Heavy metals in the environment, Scientific Institute for Husbandry and Vegetable Crops, Novi Sad.

[4] J. Wang (1985) Stripping Analysis, VCH Publishers, Derfield Beach, Florida.

[5] W. R. Jin, V. D. Nguyen, P. Valenta, H. W. Nurnberg (1997) Simultaneous determination of 7 toxic trace and or ultratrace metals in environmental plants by differential-pulse voltammetry without change of solution and eledtrode, Anal. Lett., 30(6), 1235-1254.

[6] F. Lo Coco, P. Monotti, S.Rizzotti, L. Ceccon (1999) Determination of lead in oil products by derivative potentiometric stripping analysis, Anal. Chim. Acta, 386, 41-46.

[7] D. Jagner (1978) Instrumental approach to potentiometric stripping analysis of some heavy metals, Anal. Chem., 50, 1924-1929.

[8] Z.J. Suturović, N.J. Marjanović, N. Ružić (1996) Određivanje cinka, kadmijuma, olova i bakra u crnim vinima potenciometrijskom striping analizom, Poljoprivreda, 251, 383-385.

[9] Z. J. Suturović (2003) Electrochemical Stripping Analysis, Faculty of Technology, Novi Sad.

[10] Z. Suturović, Ispitivanje uslova predelektrolize kao prve faze elektrohemijske striping analize, Magistarska teza, Tehnološki fakultet, Novi Sad, 1985.

[11] Z. Suturović, Povećanje osetljivosti potenciometrijske striping analize, Doktorska disertacija, Tehnološki fakultet, Novi Sad, 1992.

[12] Lj.M. Babincev, I.D. Novaković, M.B. Rajković, Lj.V. Rajaković (2005) Određivanje olova u reci lbar metodom potenciometrijske striping analize (PSA), VI Međunarodna Eko-konferencija 2005, Zaštita životne sredine gradova i prigradskih naselja, Novi Sad, Monografija I, Sesija 1b: Delovi žţivotne sredine - voda, p.153-158.

[13] Lj. Babincev, Lj. Rajaković, M. Barać, N. Vitas (2009) Accumulator plants used in system for resolving global eco-problems, Ecologica, 16(55), 379-383.

[14] Lj. Babincev, Lj. Rajaković, M. Budimir, S. Anđelković (2010) Content of heavy metals in biomass of natural grasslands, XII International Symposium on Forage Crops of Republic of Serbia, Biotechnol. Anim. Husb. 26, 435-442.

[15] Lj. Babincev, Lj. Rajaković, M. Budimir (2010) Extraction of lead, cadmium and zinc on vitreous carbon, International Conference Extraction of the organic compounds ICEOC-2010, Voronezh, Russia, Book of abstracts, p. 169. 
[16] Lj. Babincev, Lj. Rajaković (2010) Determination of the lead content in spinach by utilization of the potentiometric stripping analysis, Journal of engineering and processing management, 2(3), 35-44.

[17] Lj. Babincev, Analiza sadržaja teških metala u vodama oko jalovišta rudnika Suva ruda, Magistarska teza, Tehnološko-metalurški fakultet, Beograd, 2004.

[18] B.M. Kaličanin (2009) Determination of very toxic metal - Cadmium in natural water samples, Desalination, 249, 58-62.

[19] B.M. Kaličanin, N.J. Marjanović, Z. J. Suturović (2001) Determination of the soluble lead in the glass ware by the potentiometric stripping analysis, APTEFF, 32, 61-70.

[20] B.M. Kaličanin, G. Nikolić, R Nikolić (2005) Metal ion $(\mathrm{Cu}, \mathrm{Zn})$ migration in the agrochemicals-soilfood-man-chain, Ecologica, 12, 297-300.

[21] B.M. Kaličanin, N.J. Marjanović, Z.J. Suturović (2002) Application of Potentiometric stripping analysis with constant inverse current in the analytic step for determining lead in glassware, J. Serb. Chem. Soc., 67, 213-220.

[22] Z.J .Suturović, N.J. Marjanović, B. Pekić, D. Adamović (2001) Potentiometric stripping analysis of selected heavy metals in roadside chamomile flower, APTEF, 32, 157-162.

[23] Pravilnik o dozvoljenim količinama opasnih i štetnih materija u zemljištu i vodi za navodnjavanje i metodama njihovog ispitivanja (1994), Službeni glasnik Republike Srbije, 23, p. 553

[24] R. Kadović, M. Knežević (2002) Heavy Metals in forest ecosystems of Serbia, Faculty of Forestry University of Belgrade, Belgrade.

[25] R. Filipović-Trajković, M. Jablanovići Z. Ilić (2001) Uticaj aero-zagađenja na sadržaj teških metala u povrću poreklom iz industrijskih zona Kosmeta, Savremena poljoprivreda, 50(1-2), 37-40.

[26] R. Kastori (1997) Teški metali u životnoj sredini, Naučni institut za ratarstvo i povrtarstvo, Novi Sad.

\section{IZVOD}

\section{ODREĐIVANJE TEŠKIH METALA U ZEMLJIŠTU I BIOMASI PRIMENOM POTENCIOMETRIJSKE STRIPING ANALIZE}

$U$ ovom radu je opisana primena potenciometrijske striping analize (PSA) za određivanje olova, kadmijuma i cinka u uzorcima zemljišta i biomase. U cilju utvrđivanja optimalnih eksperimentalnih uslova ispitivan je uticaj $\mathrm{pH}$ vrednosti rastvora, vremena izdvajanja metala iz rastvora, brzine mešanja rastvora i debljine filma žive, kao radne elektrode. Uticaj ovih parametara je ispitan za pojedinačno $i$ istovremeno određivanje analiziranih metala. Postignute granice kvantifikacije pojedinačnih određivanja su za: olovo $22.5 \mu \mathrm{g} \mathrm{dm}^{-3}$, kadmijum $16.2 \mu \mathrm{g} \mathrm{dm}^{-3}$ i cink $18.8 \mu \mathrm{g} \mathrm{dm}^{-3}$. Dobiveni rezultati odstupaju od očekivanih vrednosti 1.1\%, 1.9\% i 1.8\%, za olovo, kadmijum i cink, respektivno. Pri istovremenom određivanju sva tri ispitivana jona, metoda je testirana pri sledećim koncentracijama: $45.0 \mu \mathrm{g} \mathrm{dm}^{-3}$ za olovo, $32.5 \mu \mathrm{g} \mathrm{dm}$ za kadmijum i $37.5 \mu \mathrm{g} \mathrm{dm}^{-3}$ za cink. Relativne greške simultanog određivanja su bile: $4.6 \%$ za olovo, $1.9 \%$ za kadmijum i $1.9 \%$ za cink. Obzirom da greške određivanja ne prelaze $\pm 2 \%$, osim za olovo, dobijeni rezultati ukazuju da se PSA može primeniti $i$ za istovremeno određivanje sadržaja olova, kadmijuma i cinka u zemljištu $i$ biomasi.

Ključne reči: olovo, kadmijum, cink, potenciometrijska striping analiza, zemljište, biomasa.

Naučni rad

Rad primljen: 20. 03. 2017.

Rad prihvaćen: 05. 05. 2017.

Rad je dostupan na sajtu: www.idk.org.rs/casopis

(c) 2017 Authors. Published by Inženjersko društvo za koroziju. This article is an open access article distributed under the terms and conditions of the Creative Commons Attribution 4.0 International license (https://creativecommons.org/licenses/by/4.0/) 